\title{
SpAds: Political Sherpas Bridging Minister and Civil Servant
}

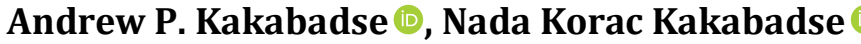 \\ Henley Business School, Greenlands, Henley on Thames, UK \\ Email: a.kakabadse@henley.ac.uk, n.kakabadse@henley.ac.uk
}

How to cite this paper: Kakabadse, A. P., \& Kakabadse, N. K. (2020). SpAds: Political Sherpas Bridging Minister and Civil Servant. Open Journal of Political Science, 10, 234-252.

https://doi.org/10.4236/ojps.2020.102016

Received: January 20, 2020

Accepted: March 17, 2020

Published: March 20, 2020

Copyright (c) 2020 by author(s) and Scientific Research Publishing Inc. This work is licensed under the Creative Commons Attribution International License (CC BY 4.0).

http://creativecommons.org/licenses/by/4.0/

(c) (i) Open Access

\begin{abstract}
This paper examines how opinion-shaping political and civil service stakeholders view the role and contribution of Special Political Advisers (SpAds) within the Westminster system of government. The literature only recently paid considered attention to this role, partly due to the recent reforms that spawned the emergence of SpAds, but also because political advisers still only represent a small population within the government community. It is acknowledged that each country's institutional and administrative traditions greatly influence SpAds' tasks; arrangements with the UK being no exception. Recognising that SpAds take on the role of "temporary civil servants" whose duties vary according to ministerial direction, the study reported in this paper concludes that SpAds can make an invaluable contribution to policy delivery by acting as a bridge between Secretary of State and Permanent Secretary. The capability to bridge the tensions between ministerial urgency to realise policy goals and civil servant realism to accurately assess the "fracture points" to be overcome in the process of policy delivery is reported as particularly valued by the public official. This paper concludes that the SpAd's relentless pursuit of the Minister's agenda is distinctly counterproductive for both Minister and civil servant, but adopting the function of bridging across contrasting interests enhances policy delivery effectiveness.
\end{abstract}

\section{Keywords}

Special Political Advisers (SpAds), Secretary of State, Permanent Secretary, Bridging Function, Policy Delivery

\section{Introduction}

Over the past two decades there has been a growing conceptual and empirical interest in the role and contribution of ministerial advisers (Fawcett and Gay, 2010; LSE GV314 Group, 2012; Shaw and Eichbaum, 2014; Hustedt et al., 2017). 
Emergent evidence suggests that ministerial advisers are playing an increasingly important role in modern democracies (Organisation for Economic Co-operation and Development (OECD, 2010); Eichbaum and Shaw, 2010; Hustedt et al., 2017). In the UK, special advisers are widely known as SpAds. In certain countries, SpAds are appointed for their professional expertise, and media and communications acumen, rather than as strategic advisers on matters of policy (OECD, 2010; Richards and Smith, 2016). In other countries where a tradition of impartiality predominates, such as Denmark, the Netherlands, and Norway, SpAds "keep" civil servants out of politics while enabling Ministers to find pathways through the growing complexity of power structures and the pitfalls of policy execution (OECD, 2010). As Peters et al. (2000: p. 21) noted, institutions and administrative traditions greatly influence specific SpAd tasks and arrangements, and these are "embedded in each country's mix of constitutional, cultural, political and administrative milieu". The UK, has witnessed an increase in SpAds (Shaw and Eichbaum, 2015a; Mangset and Asdal, 2019). The UK civil service has undergone numerous reforms and changes since the late 1980s. The Next Steps initiative created agencies intended to be at "arm's length" from ministries. These agencies maintain their own leadership, recruitment, and pay systems, as well as an independent governance through boards composed of senior ministry officials and outside non-executive directors, servicing the Minister (Cline, 2008; Page, 2010; Blach-Ørsten et al., 2019). Yet, the introduction of new technologies and the consequences of both globalization and devolution have seen certain writers promote the view that, despite all the changes, the civil service "did not actually undergo a revolution" (Cline, 2008: p. 158). Lodge (2010: p. 109) argues that despite cutbacks and criticisms of poor performance the civil service is "bouncing back" with Whitehall now experiencing a state of "normalization".

Within this setting of extensive external change but supposedly limited impact on the functioning of Whitehall, scant attention has been given to the role and contribution of SpAds despite their steady increase in numbers (Shaw and Eichbaum, 2015a). One reason for the limited attention to SpAds is the view that political advisers represent a small population within the government community and that it is civil servants who mostly and significantly interact with Ministers concerning policy development and execution (Eichbaum and Shaw, 2014; Connaughton, 2015). In contrast, others claim that the SpAd role and relationship with both the political class and the civil service is under-theorised (Eichbaum and Shaw, 2010). Shaw and Eichbaum (2015a) suggest that the Westminster-centred, first-wave SpAd analysis has sparked calls for a comparative and theoretical second wave of more intense scholarly scrutiny.

Thus, the purpose of this article is two-fold: first, to review the current insights and understandings of SpAds within the Westminster context and their impact on a non-partisan civil service (Gay, 2000, 2009; Yong and Hazell, 2014; Christensen and Opstrup, 2018) second, to present our findings from our study of the role, contribution, and impact of SpAds on the functioning of government. We conclude by emphasising the invaluable contribution SpAds make to 
the process of policy delivery and in so doing highlight areas for future research.

\section{Growing Numbers and Influence of SpAds}

The rise of what appears to be a "third element" in executive government has certain writers considering that a challenge is posed to the idealised politicsadministration dichotomy (Wilson, 1887). The cornerstone to the purpose and existence of public administration rests on the premise that politics is substantially distinct from a public administration, and that there exists a hierarchal relationship between the two (Wilson, 1887). The politics-administration dichotomy assumes public employees are "impersonal" and "apolitical", in the sense of having no political interests or political affiliation in their public role (Wilson, 1887).

Wilson (1887: p. 210) argued that the "administration lies outside the proper sphere of politics" and that "administrative questions are not political questions". He further held that, "although politics sets the task for administration, it should not be suffered to manipulate its offices" (Wilson, 1887: p. 210). It is this distinction that enables civil servants to "speak truth to power" (Wildavsky, 1979). Wilson (1887), in line with his contemporary German jurist, Bluntschli (1880), made the case for the separation of administration from both politics and the law. Thus the "Wilsonian" "arm's-length" model of bureaucracy, where administration is separate from the legislative body, forms the basis of the conventional model of government in Britain and Continental Europe (Rose, 1986: p. 4). This model operates along two dimensions: political control in the form of setting direction and maintaining oversight of policy by elected representatives, and an administration exceeding their professional independence in the process of policy execution (Connaughton, 2010; Öhberg et al., 2017). Such complementarity is based on the assumption that "both politicians and senior civil servants are highly dependent upon each other in terms of accomplishing their individual tasks in government, but simultaneously retain distinct roles" (Connaughton, 2010: p. 42; Svara, 1999, 2001; Richards and Smith, 2016). Few would argue that Ministers in the UK are considerably dependent on their officials as they do not have significant private offices or cabinets other than a limited number of SpAds (Blick, 2004). Most Westminster Ministers rely on the civil servants they inherit to put into effect the policy commitments that they are accountable to deliver (HCPACAC, 2018).

\section{SpAds in the UK Government}

Unlike their equivalents in the US, Germany, and Sweden who occupy positions with significant executive powers, UK-based SpAds do not hold formal executive power. They are not alone in this, as governments in Australia, New Zealand, Ireland, and Canada position their SpAds in a similar fashion (Eichbaum and Shaw, 2010; Page, 2010; Hustedt and Salomonsen 2017). The reason for this is that the UK has its own unique conventions (Eichbaum and Shaw, 2010) rather than being driven by a formally written constitution (House of Commons Li- 
brary, 2018).

In the UK government, a SpAd is defined as "a person that holds a position in the civil service serving the UK, Scottish or Welsh Governments and whose appointment to that position meets the appropriate requirements" (Cabinet Office, 2016: p. 2). As such, SpAds are "temporary" civil servants, personally appointed by a government minister (Constitutional Reform and Governance Act, 2010: Section 15). The Fulton Committee (1968) review of the Civil Service stipulated that SpAds should be "men and women of standing and experience". SpAds are expected to either bring an up-to-date specialist knowledge beyond that available in-house or assist the Minister to stay in touch with the world beyond Whitehall, or both (Cabinet Office, 2010b). The Code of Conduct for Special Advisers introduced in 2001 (and further revised in 2003, 2005, 2010b, 2015 and 2016, Cabinet Office, 2016: p. 2), states that the SpAd role is to assist "Ministers on matters where the work of Government and the work of the Government Party overlap and where it would be inappropriate for permanent civil servants to become involved". Thus, SpAds are an "additional resource for the Minister providing assistance from a standpoint that is more politically concerned than would be available to a Minister from the permanent Civil Service" (Cabinet Office, 2010b: column 1082). While they are guided by the Code of Conduct for Special Advisers (Cabinet Office, 2015b), SpAds are not politically impartial and are expected to support the political as well as the communications work of their Minister when related to their Minister's department (Gay, 2010; Cabinet Office, 2015b; Jenkin, 2012). The Code of Conduct for Special Advisers (Cabinet Office, 2010a, 2016: p. 2) states that SpAds are able to "request officials to prepare and provide information and data, including internal analyses and papers".

The tasks and duties undertaken by SpAds vary from Minister to Minister and range from deciding which relationships to handle and how, to suggesting new initiatives and giving a political flavour to public servants' proposals in keeping with the Secretary of State's aims and objectives (Marsh et al., 2000; Fawcett and Guy, 2010; LSE GV314 Group, 2012). In return, the Ministerial Code states that Ministers are both "responsible" and "accountable" for their SpAd's management and conduct (Public Administration Select Committee (PASC, 2012)). It is the Minister's responsibility to ensure that their advisers understand their role, the limits to their discretion to act, and the standards required from their performance (PASC, 2012; Cabinet Office, 2017a). Thus their dependency on their political masters is compared by Patapan (2012: p. 6) to Machiavelli's prince "their goodness depends on the nature of the prince". The PASC Chair, Bernard Jenkin (MP), observed that SpAds' positive contribution is "heavily dependent on a high degree of trust between them, their Ministers and their Permanent Secretaries, so there must be clarity of expectations about tasks and boundaries" (Parliament UK, 2012: p. 2).

In practice, advisers may pose both a solution and a problem in the design and operation of political/administrative relations (Table 1). When such relationships are dysfunctional, unproductive working conditions and public scandals 
Table 1. Minister, SpAd, and civil servant roles.

\begin{tabular}{|c|c|c|c|}
\hline Characteristic & Minister & SpAds & Civil Servants \\
\hline Highest title & $\begin{array}{l}\text { Secretary of the State } \\
\text { (political head of department) }\end{array}$ & Political adviser & $\begin{array}{l}\text { Permanent Secretary } \\
\text { (Administrative Head of } \\
\text { Department) }\end{array}$ \\
\hline Numbers in $2017^{1}$ & 118 & 88 & $\begin{array}{l}423,000^{2} \text { (of which less than } \\
1 \% \text { is Senior Civil Service) }\end{array}$ \\
\hline Salaries in 2017 & $\begin{array}{l}£ 155,796 \\
(\text { Cabinet Minister } £ 79,721 \\
\text { plus MP } £ 76,011)^{3}\end{array}$ & $\begin{array}{l}£ 65,000-£ 140,000 \\
\text { Median } £ 69,000 \text { (and } £ 72,000 \text { for } 32 \\
\text { SpAds who work for the Prime Minister) }\end{array}$ & Median $£ 25,900$ (March 2017) \\
\hline Ascendance to office & Elected politicians (mainly) & Appointed official & Appointed official \\
\hline Loyalty to & Party & Minister first, party second & $\begin{array}{l}\text { Must serve any government of } \\
\text { any party. No political } \\
\text { allegiance to be displayed- } \\
\text { neutral/impartial- } \\
\text { "neutral on the government side" }\end{array}$ \\
\hline Public visibility & $\begin{array}{l}\text { High public profile } \\
\text { Publicly accountable }\end{array}$ & $\begin{array}{l}\text { Potentially visible outside, } \\
\text { as well as within, Whitehall }\end{array}$ & $\begin{array}{l}\text { Anonymous-expected to offer } \\
\text { confidential and neutral advice, } \\
\text { behind closed doors }\end{array}$ \\
\hline Function & Runs department & $\begin{array}{l}\text { Works for the Minister } \\
\text { and government }\end{array}$ & Works in department \\
\hline Role & $\begin{array}{l}\text { Makes political decisions/policy } \\
\text { A number of inter-related roles } \\
\text { (advancing/defending the Government; } \\
\text { management role) }\end{array}$ & $\begin{array}{l}\text { Provide party political assistance } \\
\text { Reviewing papers, checking facts } \\
\text { from a party-political viewpoint } \\
\text { Contributing to policy planning } \\
\text { Briefing party MPs } \\
\text { Liaising with outside interest groups }\end{array}$ & $\begin{array}{l}\text { Advice on policy } \\
\text { Prepare legislation } \\
\text { Drafting answers to } \\
\text { Parliamentary questions } \\
\text { Implementing and managing } \\
\text { policy } \\
\text { Proactive guardians of propriety } \\
\text { within their departments }\end{array}$ \\
\hline Responsibility to & $\begin{array}{l}\text { Parliament, for their actions and for } \\
\text { policies directly associated with them, } \\
\text { as well as for the actions and } \\
\text { behaviour of their SpAd(s) }\end{array}$ & Minister & Minister \\
\hline Tenure & $\begin{array}{l}\text { Politician-Until next election } \\
\text { Reshuffling of the Cabinet by } \\
\text { Prime Minister-average } 2 \text { years }\end{array}$ & $\begin{array}{l}\text { Temporary civil servant-dependent } \\
\text { on ministerial tenure and favour }\end{array}$ & $\begin{array}{l}\text { Permanent-do not change at } \\
\text { time of election } \\
\text { The average tenure in post for } \\
\text { members of the SCS is } 2 \text { years } \\
\text { (HCPACAC, 2018) }\end{array}$ \\
\hline Statutory guidance & Ministerial Code (2018) & $\begin{array}{l}\text { Code of Conduct for } \\
\text { Special Advisers (December 2016) }\end{array}$ & $\begin{array}{l}\text { Civil Service Commission (2015) } \\
\text { and Civil Service Management } \\
\text { Code (2016) }\end{array}$ \\
\hline
\end{tabular}

Source: Compiled by authors.

${ }^{1}$ House of Commons Library (2018), Limitations on the number of ministers, Briefing Paper, Number 03378, 10 August,

http://researchbriefings.files.parliament.uk/documents/SN03378/SN03378.pdf.

2"Whitehall", i.e. the "head offices" of most ministries, accounts for about $9 \%$ of all civil servants.

${ }^{3}$ Combined Ministerial and Parliamentary salaries. The basic annual salary for an MP from 1 April 2017 was $£ 76,011$. MPs also receive expenses to cover the costs of running an office, employing staff, having somewhere to live in London and in their constituency, and travelling between Parliament and their constituency. Salaries of Members of Her Majesty's Government July 2016,

https://assets.publishing.service.gov.uk/government/uploads/system/uploads/attachment_data/file/561941/ministerial_salaries_july_2016_update d_17_10_16.pdf. 
are likely outcomes (Hood and Lodge, 2006; Eichbaum and Shaw, 2010; Tiernan, 2007; Laughrin, 2014). Sir Alan Walters, adviser to Margaret Thatcher, clashed publicly with Chancellor Nigel Lawson, resulting in both men resigning and, in turn, contributing to the Prime Minister's downfall a year later (Travis et al., 1989). For Alastair Campbell, Tony Blair's press secretary, "duties" included embroidering intelligence dossiers (Cameron, 2012).

From such experiences and according to Hope (2012), certain MPs, such as Gareth Thomas who was at the time Shadow Cabinet Office Minister, perceived the increased number of SpAds as a "spadocracy" (Cabinet Office, 2015b) while Labour MP John Mann saw them as "spinocracy" (Table 2). In contrast, others took a more positive view and positioned SpAds as a "mini-profession" that deserves serious attention (Hazell et al., 2012; Hustedt and Salomonsen, 2017).

The Ministerial Code (Cabinet Office, 2010a, 2010b: Section 3) stipulates that "all special advisers must uphold their responsibility to the Government as a whole, not just their appointing Minister". It was also recognised by PASC (2012: p. 3) that "the position of special advisers is a sensitive one", as "they occupy influential positions within Whitehall and have the potential to destabilise the relationship between ministers and officials". Despite the establishment of contracts and codes of conduct (Cabinet Office, 2015b, 2016), SpAds continue to perform slightly blurred and amorphous roles that provoke speculation and incur the irritation of some. Bernard Jenkin MP (Jenkins, 2012) argued that SpAds should be neither "shady characters practising the political dark arts" nor "political bag carriers" for elected members.

Irrespective of the threat posed by or value gained from SpAds, there is a history of them progressing to various leading roles within Parliament and the Executive (LSE GA314 Group, 2012; Glencross, 2015; Mangset and Asdal, 2019). The forerunner to the modern day SpAd, Thomas Cromwell, was first Henry VIII's adviser before he ascended to a ministerial role (CSW, 2009; History Extra, 2014). In more recent times, David Cameron ascended from SpAd to the role of Prime Minister, George Osborne to Chancellor of the Exchequer, Nick Clegg to Deputy Prime Minister, Ed Miliband to Labour leader, David Miliband to Foreign Secretary, and Ed Balls to Shadow Chancellor. In a similar fashion, Lord Andrew Adonis, Jack Straw, James Purnell, and Oliver Dowden all ascended to Secretary of State posts (LSE GA314 Group, 2012; Glencross, 2015; HCPACAC, 2018). In these cases, the SpAd experience acted as an apprenticeship allowing the individual to acquire the political skills not only to advance their ministerial career but also to learn how to operate effectively within the Whitehall system and sensitively interact with the media (Riddell et al., 2011; Kidd and RoseI, 2017). The route from SpAd to Minister as noted by Riddell et al. (2011: p. 28) "has been more common on the Labour than on the Conservative side".

In effect, SpAds occupy a narrow space between elected politicians and the formal structures of the civil service (Hazell et al., 2012; Christensen and Opstrup, 2018). However, SpAds carry with their role referent power and the authority of the Minister they serve. Referent power is rooted in the affiliations one 
Table 2. Governments and SpAds numbers.

\begin{tabular}{|c|c|c|}
\hline Prime Minister & Government & SpAds \\
\hline $\begin{array}{c}\text { Kings and } \\
\text { Prime Ministers }\end{array}$ & Various governments through the ages & $\begin{array}{l}\text { Without any formal system, Kings, Prime Ministers and individual } \\
\text { Ministers brought in particular advisers. Such advisers were friends, } \\
\text { cronies, colleagues. } \\
\text { Until 1920, personal and political appointees were commonplace } \\
\text { serving in the Prime Minister's private office (Jones, 1978). }\end{array}$ \\
\hline Harold Wilson & $\begin{array}{l}\text { - Labour government, } 1964-1970 \\
\text { - } \quad \text { Labour government, 1974-1976 }\end{array}$ & $\begin{array}{l}\text { - Formalised SpAd-specific roles and job titles (Wilson, 1976: p. 98). } \\
\text { - Appointed as temporary civil servants, "experts" such as } \\
\text { Thomas Balogh. } \\
\text { - The term "Special Adviser" (SpAd) commonly used for the } \\
\text { first time in } 1975 . \\
\text { - Ministers allowed to appoint SpAds on a regular basis. } \\
\text { - } 38 \text { SpAds in 1974, dropped to } 24 \text { in } 1976 \text {. }\end{array}$ \\
\hline James Callaghan & $\begin{array}{l}\text { Labour government, } \\
1976-1979\end{array}$ & $\begin{array}{l}\text { - Surrounded himself with shrewd academic advisers. } \\
\text { - Reduced number of SpAds from } 29 \text { to } 24 \text { (Knight, 1990: p. 105). }\end{array}$ \\
\hline Margaret Thatcher & Conservative government, $1979-1990$ & $\begin{array}{l}\text { - Initially hostile to political advisers, as opposed to expert advisers } \\
\text { (Burch, 1983). } \\
\text { - } 20 \text { SpAds in the early days }\end{array}$ \\
\hline John Major & Conservative government, 1990-1997 & - $\quad 38$ SpAds in 1997 \\
\hline Tony Blair & New Labour administration, 1997-2007 & $\begin{array}{l}\text { - Between } 70 \text { and } 84 \text { SpAds during his office ( } 70 \text { in 1998; } 82 \text { in 2004). } \\
\text { - SpAds increased in numbers; greater influence over career civil } \\
\text { servants; perceived privileged position as policy shapers. } \\
\text { Two SpAds, Jonathan Powell and Alastair Campbell, } \\
\text { were given executive powers over civil servants. }\end{array}$ \\
\hline Gordon Brown & New Labour administration, 2007-2010 & $\begin{array}{l}\text { - } \quad 73 \text { SpAds in } 2008 \\
\text { - } \quad 74 \text { SpAds in } 2010\end{array}$ \\
\hline David Cameron & $\begin{array}{l}\text { Conservative and Liberal Democrat } \\
\text { coalition government, 2010-2016 }\end{array}$ & $\begin{array}{l}\text { - } 98 \text { SpAds in } 2013 \text {. } \\
103 \text { SpAds in } 2014 / 5 \text { (increase was following the decision by the then } \\
\text { Deputy Prime Minister, Nick Clegg, to expand his political operation). } \\
\text { - } 92 \text { SpAds in } 2015 \text { reduced to } 83 \text { (one SpAd in Downing } \\
\text { Street and } 11 \text { from the key Whitehall departments). }\end{array}$ \\
\hline Theresa May & $\begin{array}{l}\text { Conservative government } \\
\text { - 2016-2017 }\end{array}$ & - $\quad 88$ SpAds in 2017. \\
\hline
\end{tabular}

Source: Table draws together different sources of information, including Cabinet Office 2017a; Cabinet Office 2017b; Cabinet Office 2017c; and designed by the authors.

derives from the groups and organisations to which one belongs (Raven, 1965; Kidd and RoseI, 2017). Thus, the ethos of the SpAds association with the Minister becomes, to some degree, his/her ethos. In hierarchical relationships, those who have real or perceived power, such as having access to their superior, have influence. SpAds have that access to the Minister, while civil servants are increasingly becoming devoid from such intimate access.

Based on the work for the Royal Commission, Australian Government Administration, and earlier work by Walter (1986), Smith (1976: p. 305) concluded that the position of adviser is anomalous as it holds that the "relations between ministers and their public service advisers do not provide for the easy inter-positioning of policy orientated ministerial staff" (Smith, 1977: p. 149). The 
considered view is that the advisers' presence "disrupts accepted patterns of bureaucratic influence" irrelevant of "how skilled and tactful ministerial advisers" may be (Smith, 1977: p. 149). Thus, SpAds mediate the zone between politics-which is about setting policy and making decisions on how to best meet the publics' need-and policy execution (Whitaker, 2000; Kidd and RoseI, 2017). The former is an activity that is inevitably partisan, complex, and sometimes controversial, and it rests within the domain of an elected politician, the Minister (Whitaker, 2000; Inwood, 2009; Blach-Ørsten et al., 2019). The Minister's duty is to debate, politicise, and communicate policy through their party's manifesto and make pertinent decisions (Inwood, 2009). The latter is the task of public administration and rests in the domain of civil servants (Whitaker, 2000). Thus, despite the scrutiny undertaken, the role of SpAds continues to be subject to ongoing debate concerning their task, role, contribution, numbers, and cost (House of Commons, 2018).

\section{The Study}

This study explores how the SpAd—an elite actor appointed according to ministerial discretion-contributes to policy design and delivery. The focus on the SpAd illuminates a spectrum of other actors-Prime Minister, Ministers, departmental boards, senior civil servants, arm's-length agencies-all of whom play a role in shaping and coordinating policy. Using a combination of purposive and snowball sampling techniques, individuals who could provide insights relevant to the inquiry were targeted by the researchers (Bryman, 2012; Tansey, 2007). A total of 81 confidential, elite interviews (Delaney, 2007; Kakabadse and Louchart, 2012) were carried out with current and former Secretaries of State, Junior Ministers, SpAds, Permanent Secretaries, Directors Generals and other civil servants, non-executive directors on departmental boards, chairpersons/CEOs of arm's length bodies and outsourcing agency executives in the period from late 2016 to early 2018. During interviews, we were exploring the blockages at senior level to policy delivery. In transcribing the interviews, the use of gendered pronouns has been amended to ensure confidentiality for all parties involved. The term "elite" in this study refers to a heterogeneous group of actors who have influence at the highest decision-making levels in government and related bodies regarding policy formulation and execution. We consider the SpAds as elite because the role is strategically positioned between Minister and civil servant (Burt, 1992).

We conducted inductive data analysis identifying themes emergent from the interview transcripts (Smith et al., 2009). The analysis employed a broad thematic discourse framework, where findings were based on the recurrent themes, patterns, and categories that surfaced in the transcribed conversations (Deacon et al., 2007). We employed the process of "close reading", which requires a detailed reading and re-reading of the text (Alvesson and Skoldberg, 2009) with importance being given to the lived experiences of the respondents, which 
shaped their perceptions of the role, challenges, and contribution of SpAds (Langdridge, 2007). Content was then coded to identify and label emergent themes. Themes were derived by combining and comparing the thematic findings from all participant groups (Kakabadse and Louchart, 2012). The final thematic structure was agreed following detailed collaboration between the two authors, who discussed and reanalysed any discrepancies as well as confirmed themes and ensured that the selected quotes were representative. The four emergent themes are now outlined with representative quotes from the interviews.

\section{Study Findings}

As stated, four themes emerged from analysis: 1) ministerial self-responsibility, 2) Ministers' mistrust of civil servants, 3) civil servants' service to the Minister, and 4) urgency versus realism, which gives rise to the bridging function of the SpAd. Although there may be some overlap across these themes, we hold them conceptually apart, drawing out key implications.

\section{Ministerial self-responsibility}

Participating Ministers expressed two contrasting views concerning the role, contribution, and value of SpAds. One perspective is that SpAds are useful in carrying out the Minister's bidding across a variety of stakeholder groups. Ministers acknowledged that they are under pressure to act rapidly, as much dictated by the electoral cycle, limited ministerial tenure, and media pressure, all contributing to exercise the "urgency of the political imperative". SpAds are viewed as being responsive to such demands through easing the pressure on the Minister as well as producing a buffer between them and other stakeholder groups.

"Those advisers in whom I had faith acted promptly and appropriately."-Secretary of State.

"It was me that sorted out those relationships between him [the Minister] and those others. I am not sure he is fully appreciative of the lengths I had to go [to]..."-SpAd.

Thus, SpAds promoting the Minister's agenda, protecting the Minister from reputational damage and, albeit to a lesser extent, coordinating with other SpAds to push through policy or seek inter-party agreement emerged as key elements of the SpAd's role as desired by the Minister. The coordination role, however, was often described as promoting the Ministers' partisan agenda and safeguarding their reputation. It was certainly clear that the SpAd's role is fraught and complex, and highly dependent on ministerial discretion.

The alternative view offered by Ministers was that of a distinct distaste for SpAds. Criticism focused on other Ministers who were viewed as not accepting responsibility for their own actions and decisions as well as displaying the personal weakness of "hiding" behind the SpAd. The distaste for SpAds centred on them acting as a shield behind which the Minister can "manipulate" a way forward in order to realise their own agenda. Ministers criticised Ministers, par- 
ticularly when advice comes from the SpAd rather than the impartial perspective offered by civil servants.

"They $[S p A d s]$ are a menace. Their Minister, even worse, hiding behind the SpAd and not having the guts to address challenges openly. When the Minister needs Rottweilers [referring to SpAds] we all know things ultimately will go wrong."-Secretary of State.

"I do find these special advisers quite unnecessary. They are little more than the outward ego of the Secretary of State. Making the Secretary of State look good when that very same person does not have the strength to do his own dirty work. These SpAds play on that to the maximum."-Secretary of State.

Our findings confirm that SpAds are seen to play the role of policy wonks, enforcers, fixers (as suggested by LSE GV314 Group, 2012), as well as acting as political "sherpas" (according to Shaw and Eichbaum, 2014 and Askim et al., 2017). Inadvertently, our study identified SpAds' support for the Ministers in terms of the need for "ego-boosting" (Young and Sloman, 1982: p. 88) but not acting as a "medieval fool". Rather, SpAds are used by certain Ministers to protect themselves and minimise the tarnishing of the Minister's reputation.

\section{Ministers' Mistrust of Civil Servants}

The majority of Ministers in the study expressed their trust in civil servants. However, there was a significant minority who declared a mistrust of civil servants and for that reason drew on the services of SpAds to aggressively push the Minister's agenda. In response, certain SpAds have vigorously and aggressively pursued the ministerial agenda, which observers viewed as being to the detriment of those directly concerned, including the Minister. The push to realise ministerial urgency was considered as particularly damaging for civil servants. The attitude and behaviour of the SpAd were described as between "over-assertive" and "aggressive".

"[I] $f$ they simply see their role as enforcers for the Minister and are not capable of being sufficiently open and intelligent enough to make their own assessment and then guide their Minister or Secretary of State accordingly. They're not up to the job."-Permanent Secretary.

The unwelcome impact of certain SpAds is reported by others than civil servants.

"The Special Advisers have their own agendas, slightly out of control ... the Minister has significantly reduced the number of Special Advisers and I think that's been a very positive thing." - Non-Executive Director, Departmental Board.

Yet other respondents indicate that the unwelcome "pushy" behaviour of SpAds is now more a phenomenon of the past. Since the last election (2017), the style of the SpAd is seen to have become more facilitative. Paying greater attention to their listening skills and a greater willingness to work with the Permanent Secretary to genuinely explore how policy could be better delivered is seen as the current approach taken by certain SpAds. Permanent Secretaries see this development as positive. 
"[ T] he Civil Service has largely adjusted to that now, and mostly for the better in my experience. The relationship with Special Advisers is a productive one. They can provide a political insight which civil servants typically are less able to do."-Permanent Secretary.

"My best friend. I now probably spend more time with the SpAd, having a coffee and trying to see how the message should be positioned to the Minister's advantage. For me they are invaluable."-Permanent Secretary.

Most interviewees agreed that the more thoughtful, cooperative, and facilitative the SpAd, the better the quality of advice to the Minister. In the opinion of the respondents, the damaging circumstances of the past appear to have changed in the summer of 2017 after the Prime Minister dismissed her two most senior aides, Fiona Hill and Nick Timothy, in response to complaints made that these SpAds held undue power at the centre of government (Elgot and Mason, 2017). Fiona Hill and Nick Timothy were known for their confrontational style, with certain MPs complaining they acted more like Deputy Prime Ministers than unelected advisers (Elgot and Mason, 2017).

Where concern with SpAds still prevails is their involvement with the lower ranks of the Civil Service. One Permanent Secretary reluctantly acknowledged that, despite improvements, civil servants lower in the hierarchy are exposed to undue "spAd aggressive behaviour".

"They can be enormously helpful and really help officials ... There are others who just strike fear and terror into the hearts of civil servants and diminish the competence of the whole organisation and I've certainly come across a good number of those."-Permanent Secretary.

"Well, they' re a very mixed bag. There are some who are absolutely outstanding... and there are some who are completely destructive forces within the Department for whatever reason ... There are other ones who are bad because they very tightly control access to the Secretary of State."-Permanent Secretary.

The interviewees considered that both Minister and civil servants should give greater attention to SpAd appointment criteria. Further, following Cabinet reshuffles, certain SpAds move to other departments accompanying their Minister. Such moves are acknowledged as not being based on functional knowledge or skills, but rather on the nature of the trusted working relationship between the Minister and the SpAd.

\section{Servicing the Minister}

All of the civil servant respondents strongly declared their belief in representative democracy and their devoted support to the Minister who is viewed as the fundamental building block of representative democracy. In providing service to the Minister, a number of interviewees stated that being attuned to the Minister requires building a broad network of trusting stakeholder relationships, which can be called upon to facilitate the Minister realising his/her objectives.

"I think one of the strengths of civil servants, which is largely hidden from Ministers, is that civil servants were always very good about their wider relationships. Their ability to have the connections in the fields-they know they go 
to people who could either reinforce the argument they wanted to push or stop the Minister doing something." - Secretary of State.

"I want the Minister primarily to be clear about the direction they want to go in, provide the appropriate framework for us to work in, to appropriately challenge but actually at a level that recognises that the people who are responding want to deliver what Ministers want them to deliver."-Permanent Secretary.

Concerning civil servant support of the Minister, Barberis (1996: p. 91) concludes that, given the pivotal role of Permanent Secretaries, "no one can swing a whole department behind a major policy initiative as can a Permanent Secretary". The respondents noted that the role of Permanent Secretary is that of chief adviser, chief conduit of advice to Ministers, as well as being orchestrator of policy and the strategic managers for the department.

In their support of Ministers, numerous civil servants reported the lengths they go to consistently and cohesively work with SpAds. In order to minimise the SpAd negative effect, certain Permanent Secretaries report that they act as a "buffer" between the SpAd and the staff of their department.

"I also make it very clear to them that if they've got a problem with any of the work that the staff are doing that they should tell me about it, not the staff. What you don't want is a Special Adviser shouting at your staff because that's not the way to get the best out of people..."-Permanent Secretary.

In contrast, other Permanent Secretaries highlight that certain SpAds have made a positive contribution.

"[ T] here's three types really. There's the type that is very influential with a Secretary of State but regard their relationship with the Department as a combative one. There are the ones who are very influential with the Secretary of State but regard their relationship with the Department as an important and collaborative one. And there are ones who aren't that influential with the Secretary of State and aren't having as huge an impact on the department in any case." Permanent Secretary

Despite perceived improvements in SpAd attitude and behaviour, disquiet remains concerning the privileged access political advisers have to Ministers potentially permitting the inappropriate usurpation of executive authority (Parliament UK, 2012; Wicks, 2002). In effect, the behaviours of certain SpAds continue to be unwelcomed.

\section{Urgency versus Realism: The Bridging Function of SpAds}

The most valued SpAds are those who make it their priority to engage with Minister and Permanent Secretary in particular, and other civil servants and relevant stakeholders when faced with conflicting and contradictory agendas. The predisposition of the Minister is that of urgency-to have policy delivered within the time frames stated or implied. The focus of the civil servants is that of "realism", namely to accurately assess the landscape and spread of misaligned agendas facing the Minister so as to ensure for greater engagement from varying stakeholders that the policy in question can be effectively delivered. Those SpAds that find ways to engage with "both sides", despite conflicting interests, 
act as a bridge and through so doing are considered the most effective. They are reported as being warm, good listeners, reflective, intellectually sharp, and realistic about "manoeuvring" through a landscape of contradictory interests. This study highlights that SpAds can greatly contribute to bridging this chasm through working closely with senior civil servants who often have more knowledge and experience of the department.

"If it were not for my relationship between my Secretary of State and that other one, we would have resulted in a complete breakdown... through both Permanent Secretaries I got the various parties talking."-SpAd.

Eichbaum and Shaw (2010) question whether the advent of SpAds has reconfigured the balance between independence and responsiveness, and question how the expectations and risks posed by these agents are managed. Our study highlights that this depends predominately on the discretion of the Minister as well as that of the SpAd, and to some extent the discretion of the Permanent Secretary. SpAds are in a position to carefully weigh up the Minister's and civil servant's advice against their own moral and ethical principles and make their own judgement and, in so doing, advise the Minister, and at times the Permanent Secretary, concerning the best course of action to take in that specific context.

In effect, the role of SpAd attracts a range of comment according to the style and tactics adopted and the context in which discretionary action is played out.

"I had to confront him [ the Secretary of State] and say without me you would be facing a disaster. These others are not too difficult to handle. It's keeping him [ the Secretary of State] in touch."-SpAd.

While in the past, Permanent Secretaries saw themselves as the 'broker' between the Minister and the department (Rouban, 2012), SpAds are emerging as partly fulfilling this role in acting as the bridge between the Minister and the Permanent Secretary. Especially this is the case when faced with a delicate party matter where the Minister feels it desirable to use a personal confidant to carry out brokerage negotiations.

\section{Conclusion}

SpAds' ability to balance the accuracy of policy assessment (i.e. civil service input) with the urgency for achieving ministerial outcomes is recognised as invaluable by civil servants. In contrast, SpAds who exclusively pursue ministerial desires spawn unwelcome conflict and tension with often undesired consequences for the Minister and civil servants. This finding in some ways provides an answer to Eichbaum and Shaw's (2010) question concerning whether the advent of political staff has reconfigured the balance between independence and responsiveness, and how the expectations and risks posed by these agents are managed.

SpAds, however, face what Dror (1985: p. 193) calls "inherent" dilemmas, that of providing "objective estimates and professional analysis" (the content) and adjusting to "the emotional needs of the recipient or to his possible emotional 
reactions". Effective SpAds are ones who work through Dror's (1985) inherent dilemma; that of building relationships and bridges through the establishment of trust with the Minister as well as with other stakeholders, especially civil servants.

Ultimately, the policy process is political, involving value judgements and debates about collective action and therefore has an irreducible political and discretionary element to it. The role of SpAd emerges as "bridging" the Minister and the civil servant, and other stakeholders, rather than being a broker acting as "middleman between the social science, bureaucratic and political decision-making worlds" (Francesca and Stoker, 2011: p. 495). The challenge will be in choosing between Minister and civil servant when the policy delivery pathways run in contrasting directions. Such dilemmas are worked through, or not, by the ethical framework of the SpAd. How to tell the Minister that their course of action is ill-advised is by nature no easy matter.

What this study concludes is that SpAds have "a very good friend" in the Permanent Secretary and together they can position messages that enhance the Minister's interests. When that is impossible, the Minister's interests must prevail; a point fully appreciated by the civil servant irrespective of their views on best pathway for policy delivery. The SpAd who makes a positive contribution emerges as the one who concludes the Minister's agenda must be pursued when all other avenues have been explored, rather than enforcing such an agenda without a full examination of context. It is the examination of context and the understanding of how to engage across misaligned interests that surfaces the pathway of how to best execute the Minister's agenda. The SpAd's sensitivity to such a process makes them trusted by the critical players involved.

Our study shows the importance of SpAds being the strategic mediation between the Permanent Secretary/civil service team and the Secretary of State. The reason for mediation is due to two contrasting interpretations of time. The Secretary of State's perspective concerning urgency to fulfil political commitments and obligations is contrasted against that of the Permanent Secretary's attention to realism, namely the appraisal of the blockages and misalignments to work through to have policy effectively delivered. The pressures on both parties require someone independent to facilitate greater understanding between the two parties to ensure for on-time delivery of policy.

\section{Where from Here?}

The limitation of this study is that it is a cross-sectional qualitative investigation. As such, it is valid within the parameters of a particular time frame and the participating population. Further work needs to be carried out with SpAds to identify the blockages, constraints and supports in their role, the nature of their allegiances and to whom and the skills and qualities required to add value.

\section{Conflicts of Interest}

The authors declare no conflicts of interest regarding the publication of this paper. 


\section{References}

Alvesson, M., \& Skoldberg, K. (2009). Reflexive Methodology: New Vistas for Qualitative Research (2nd ed.). London: Sage.

Askim, J., Karlsen, R., \& Kolltveit, K. (2017). Political Appointees in Executive Government: Exploring and Explaining Roles Using a Large-N Survey in Norway. Public Administration, 95, 342-358. https://doi.org/10.1111/padm.12272

Barberis, P. (1996). The Elite of the Elite: Permanent Secretaries in the British Higher Civil Service. Aldershot: Dartmouth Publishing Company.

Blach-Ørsten, M., Mayerhöffer, E., \& Willig, I. (2019). From Government Office to Private PR: Career Patterns of Special Ministerial Advisers and the Privatization of Politics. The International Journal of Politics, 1-19.

Blick, A. (2004). People Who Live in the Dark. The History of the Special Adviser in British Politics. London: Politicos.

Bluntschli, J. K. (1880). German State Doctrine and the Present World of States.

Bryman, A. (2012). Social Research Methods. Oxford: OUP.

Burch, M. (1983). Mrs Thatcher's Approach to Leadership in Government: 1979-1983. Parliamentary Affairs, 36, 398-416. https://doi.org/10.1093/pa/36.4.399

Burt, R. S. (1992). Structural Holes. Cambridge, MA: Harvard University Press.

Cabinet Office (2010a). Ministerial Code. National Archive, May. http://webarchive.nationalarchives.gov.uk/+/http:/www.cabinetoffice.gov.uk/media/40 9215/ministerialcodemay2010.pdf

Cabinet Office (2010b). Code of Conduct for Special Advisers. London: Cabinet Office.

Cabinet Office (2015b). Special Adviser Data Releases: Numbers and Costs. Cabinet Office.

https://www.gov.uk/government/publications/special-adviser-data-releases-numbers-a $\underline{\text { nd-costs-december-2015 }}$

Cabinet Office (2016). Code of Conduct for Special Advisers. Cabinet Office. https://assets.publishing.service.gov.uk/government/uploads/system/uploads/attachme nt_data/file/832599/201612_Code_of_Conduct_for_Special_Advisers.pdf

Cabinet Office (2017a). List of Special Advisers in Post as at December 2017. Transparency Data.

https://www.gov.uk/government/publications/special-adviser-data-releases-numbers-a nd-costs-december-2017

Cabinet Office (2017b). Annual Report and Accounts. Assets Publishing Service. https://assets.publishing.service.gov.uk/government/uploads/system/uploads/attachme nt_data/file/646841/CO_Annual_Report_2016-17.pdf

Cabinet Office (2017c). Special Adviser Data Releases: Numbers and Costs. Gov.uk. https://www.gov.uk/government/publications/special-adviser-data-releases-numbers-a nd-costs-december-2017

Cameron, S. (2012). Stand Up, You Spads, and Be Accountable. The Telegraph. https://www.telegraph.co.uk/news/politics/9241164/Stand-up-you-Spads-and-be-accou ntable.html

Christensen, J. G., \& Opstrup, N. (2018). Bureaucratic Dilemmas: Civil Servants between Political Responsiveness and Normative Constraints. Governance, 31, 481-498.

https://doi.org/10.1111/gove.12312

Civil Service Commission (2015). The Civil Service Code. Gov.uk. https://www.gov.uk/government/publications/civil-service-code/the-civil-service-code 
Civil Service Management Code (2016). UK Government, 16 March.

https://www.gov.uk/government/publications/civil-service-code/the-civil-service-code

Cline, A. W. (2008). The Modernisation of British Government in Historical Perspective. Parliamentary Affairs, 61, 144-159. https://doi.org/10.1093/pa/gsm050

Connaughton, B. (2010). Glorified Gofers, Policy Experts or Good Generalists: A Classification of the Roles of the Irish Ministerial Adviser. Irish Political Studies, 25, 347-370. https://doi.org/10.1080/07907184.2010.497636

Connaughton, B. (2015). Navigating the Borderlines of Politics and Administration: Reflections on the Role of Ministerial Advisers. International Journal of Public Administration, 38, 37-45. https://doi.org/10.1080/01900692.2014.952820

Constitutional Reform and Governance Act (2010). UK Government. https://www.legislation.gov.uk/ukpga/2010/25/contents

CSW (2009). Special Report: Out of the Darkness. Civil Service World. https://www.civilserviceworld.com/special-report-out-of-the-darkness

Deacon, D., Pickering, M., Golding, P., \& Murdock, G. (2007). Researching Communications: A Practical Guide to Methods in Media and Cultural Analysis (2nd ed.). London: Hodder Arnold.

Delaney, K. J. (2007). Methodological Dilemmas and Opportunities in Interviewing Organizational Elites. Sociology Compass, 1, 208-221. https://doi.org/10.1111/j.1751-9020.2007.00028.x

Dror, Y. (1985). Policy Making Under Adversity. New Brunswick, NJ: Transaction Books.

Eichbaum, C., \& Shaw, R. (2010). Partisan Appointees and Public Servants. An International Analysis of the Role of the Political Adviser. Cheltenham: Edward Elgar. https://doi.org/10.4337/9781849803298

Eichbaum, C., \& Shaw, R. (2014). The Mortal Temples of the King: Prime Ministers and Their Advisers in Parliamentary Democracies. In R. A. W. Rhodes, \& P. t'Hart (Eds.), The Oxford Handbook of Political Leadership (pp. 517-532). Oxford: OUP. https://doi.org/10.1093/oxfordhb/9780199653881.013.020

Elgot, J., \& Mason, R. (2017). Nick Timothy and Fiona Hill: Unelected Advisers Who Acted More like DPMs. The Guardian.

https://www.theguardian.com/politics/2017/jun/10/nick-timothy-and-fiona-hill-unelec ted-advisers-who-acted-more-like-dpms

Fawcett, P., \& Gay, O. (2010). The United Kingdom. In C. Eichbaum, \& R. Shaw (Eds.), Partisan Appointees and Public Servants: An International Analysis of the Role of the Political Adviser (pp. 24-36). Cheltenham: Edward Elgar.

Francesca, F., \& Stoker, G. (2011). Special Advisers and the Transmission of Ideas from the Policy Primeval Soup. Policy and Politics, 39, 485-498.

https://doi.org/10.1332/030557310X550169

Fulton Committee (1968). The Civil Service, Vol. 1, Report of the Committee 1966-1968. https://www.scribd.com/document/283634741/Fulton-Committee-I

Gay, O. (2000). Advisers to Ministers (Research Paper 00/42). London: Parliament and Constitution Centre, House of Commons Library.

Gay, O. (2009). Special Advisers. London: House of Commons Library Standard Note $\mathrm{SN} / \mathrm{PC} / 03813$.

Gay, O. (2010). Special Advisers (Standard Note SN/PC/03813). London: Parliament and Constitution Centre, House of Commons Library.

Glencross, T. (2015). Attack of the Clones: How Spads Took over British Politics. The 
Guardian.

https://www.theguardian.com/politics/2015/apr/19/spads-special-advisers-took-over-b ritish-politics

Hazell, R., Yong, B., Waller, P., \& Walker, B. (2012). Submission to the Public Administration Committee Inquiry on Special Advisers, the Constitution Unit, University College London. Parliament UK.

https://publications.parliament.uk/pa/cm201213/cmselect/cmpubadm/134/134we10.htm

HCPACAC (House of Commons Public Administration and Constitutional Affairs Committee) (2018). The Minister and the Official: The Fulcrum of Whitehall Effectiveness. Fifth Report of Session 2017-19, Ordered by the House of Commons to Be Printed 12 June 2018.

History Extra (2014). Thomas Cromwell: The Rise and Fall of Henry VIII's Henchman. $B B C$ History Magazine and BBC World Histories Magazine.

https://www.historyextra.com/period/tudor/thomas-cromwell-the-rise-and-fall-of-hen rys-henchman/

Hood, C., \& Lodge, M. (2006). The Politics of Public Service Bargains. Oxford: OUP. https://doi.org/10.1093/019926967X.001.0001

Hope, C. (2012). Number of Special Advisers Employed by David Cameron and Nick Clegg Soars. The Telegraph.

https://www.telegraph.co.uk/news/9406787/Number-of-special-advisers-employed-byDavid-Cameron-and-Nick-Clegg-soars.html

House of Commons (2018). Special Advisers. Parliament UK. http://researchbriefings.parliament.uk/ResearchBriefing/Summary/SN03813

House of Commons Library (2018). Special Advisers, Briefing Paper, Number 3813. Research Briefings. http://researchbriefings.files.parliament.uk/documents/SN03813/SN03813.pdf

Hustedt, T., \& Salomonsen, H. H. (2017). Political Control of Coordination? The Roles of Ministerial Advisers in Government Coordination in Denmark and Sweden. Public Administration, 95, 393-406. https://doi.org/10.1111/padm.12312

Hustedt, T., Kolltveit, K., \& Salomonsen, H. H. (2017). Ministerial Advisers in Executive Government: Out from the Dark and into the Limelight. Public Administration, 95, 299-311. https://doi.org/10.1111/padm.12329

Inwood, G. J. (2009). Understanding Canadian Public Administration: An Introduction to Theory and Practice (3rd ed.). Scarborough: Pearson-Prentice Hall.

Jenkin, B. (2012). Avoid the Thick of It-Style SpAd Appointments, Ministers Told. The Guardian.

https://www.theguardian.com/politics/2012/oct/14/avoid-thick-of-it-appointments

Jones, G. (1978). The Prime Ministers' Men. Whitley Bulletin, April 1978, 4, 66-68.

Kakabadse, N. K., \& Louchart, E. S. (2012). Delicate Empiricism: An Action Learning Approach to Elite Interviewing. In A. P. Kakabadse, \& N. K. Kakabadse (Eds.), Global Elites: The Opaque Nature of Transnational Policy Determination (pp. 286-307). Basingstoke: Palgrave Macmillan. https://doi.org/10.1057/9780230362406_17

Kidd, C., \& RoseI, J. (2017). The Perils of Political Advice. PPR Progressive Review, 24, 243-253.

Knight, C. (1990). The Making of Tory Education Policy in Post-War Britain, 1950-1986. London: The Falmer Press.

Langdridge, D. (2007). Phenomenological Psychology: Theory, Research and Method. Harlow: Pearson Prentice Hall. 
Laughrin, D. (2014). What Special Advisers Do for Ministers. In B. Yong, \& R. Hazell (Eds.), Special Advisers. Who They Are, What They Do and Why They Matter (pp. 61-86). Oxford: Hart Publishing.

Lodge, M. (2010). Public Service Bargains in British Central Government: Multiplication, Diversification and Reassertion? In M. Painter, \& G. B. Peters (Eds.), Tradition and Public Administration (pp. 99-113). Basingstoke: Palgrave Macmillan. https://doi.org/10.1057/9780230289635_8

LSE GV314 Group (2012). New Life at the Top: Special Advisers in British Government. Parliamentary Affairs, 65, 715-732. https://doi.org/10.1093/pa/gss011

Mangset, M., \& Asdal, K. (2019). Bureaucratic Power in Note-Writing: Authoritative Expertise within the State. The British Journal of Sociology, 70, 569-588. https://doi.org/10.1111/1468-4446.12356

Marsh, D., Richards, D., \& Smith, M. J. (2000). Re-Assenting the Role of Departmental Cabinet Ministers. Public Administration, 78, 305-326.

https://doi.org/10.1111/1467-9299.00207

Ministerial Code (2018). Cabinet Office, May. http://webarchive.nationalarchives.gov.uk/ http://www.cabinetoffice.gov.uk/media/409215/ministerialcodemay2018.pdf

OECD (2010). Ministerial Advisers. Role, Influence and Management. Paris: OECD Publishing.

Öhberg, P., Christiansen, P. M., \& Niklasson, B. (2017) Administrative Politicization or Contestability? How Political Advisers Affect Neutral Competence in Policy Processes. Public Administration, 95, 269-285. https://doi.org/10.1111/padm.12253

Page, E. (2010). Has the Whitehall Model Survived? International Review of Administrative Sciences, 76, 407-423. https://doi.org/10.1177/0020852310373004

Parliament UK (2012). SpAds Need Better Training and Support: Bernard Jenkin MP, Chair of the Committee. Parliament UK.

https://www.parliament.uk/business/committees/committees-a-z/commons-select/pub lic-administration-select-committee/news/publication-of-spads-report

PASC (Public Administration Select Committee) (2012). Special Advisers in the Thick of It, Sixth Report of Session 2012-13, House of Commons. https://publications.parliament.uk/pa/cm201213/cmselect/cmpubadm/134/134.pdf

Patapan, H. (2012). Machiavellian Advisers: Political Leadership and the Problem of Policy Adviser. International Public Policy Association. http://www.ippapublicpolicy.org/file/paper/5938db34ef65b.pdf

Peters, B. G., Rhodes, R., \& Wright, V. (2000). Administering the Summit: Administration of the Core Executive in Developed Countries. New York: St Martin's Press.

Raven, B. H. (1965). Social Influence and Power. In I. D. Steiner, \& M. Fishbein (Eds.), Current Studies in Social Psychology (pp. 371-382). New York: Holt, Rinehart, Winston.

Richards, D., \& Smith, M. J. (2016). Governance: An International Journal of Policy. Administration, and Institutions, 29, 499-516. https://doi.org/10.1111/gove.12225

Riddell, P., Gruhn, Z., \& Carolan, L. (2011). The Challenge of Being a Minister: Defining and Developing Ministerial Effectiveness. Institute for Government.

https://www.instituteforgovernment.org.uk/publications/challenge-being-minister

Rose, R. (1986). A House Divided: Political Administration in Britain. University of Strathclyde Studies in Public Policy Number 158. 
Rouban, L. (2012). Politicisation of the Civil Service. In B. G. Peters, \& J. Pierre (Eds.), Handbook of Public Administration (2nd ed., pp. 380-391). London: Sage. https://doi.org/10.4135/9781446200506.n25

Shaw, R., \& Eichbaum, C. (2014). Ministers, Minders and the Core Executive: Why Ministers Appoint Political Advisers in Westminster Contexts. Parliamentary Affairs, 67, 584-616. https://doi.org/10.1093/pa/gss080

Shaw, R., \& Eichbaum, C. (2015a). Following the Yellow Brick Road: New Directions in Studying Political Advisers in Executive Government. International Journal of Public Administration, 38, 1-3. https://doi.org/10.1080/01900692.2014.980910

Smith, J., Flowers, P., \& Larkin, M. (2009). Interpretative Phenomenological Analysis. Theory, Method and Research. London: Sage.

Smith, R. F. I. (1976). Ministerial Advisers. Canberra, Appendix 1.J: Ministerial Advisers. RCAGA Appendix Volume One.

Smith, R. F. I. (1977). Ministerial Advisers: The Experience of the Whitlam Government. Australian Journal of Public Administration, 36, 133-158. https://doi.org/10.1111/j.1467-8500.1977.tb00391.x

Svara, J. H. (2001). The Myth of the Dichotomy: Complementarity of Politics and Administration in the Past and Future of Public Administration. Public Administration Review, 61, 177-183. https://doi.org/10.1111/0033-3352.00020

Svara, J.H. (1999). Complementarity of politics and administration as a legitimate alternative to the dichotomy model. Administration and Society, 30(6), 676-705. https://doi.org/10.1177/00953999922019049

Tansey, O. (2007). Process Tracing and Elite Interviewing: A Case for Non-Probability Sampling. PS: Political Science and Politics, 40, 765-772. https://doi.org/10.1017/S1049096507071211

Tiernan, A. (2007). Power without Responsibility. Sydney: UNSW Press.

Travis, A., Huhne, C., \& Wintour, P. (1989). Lawson Sparks Reshuffle. The Guardian. https://www.theguardian.com/politics/1989/oct/27/past.christopherhuhne

Walter, J. (1986). The Ministers' Minders: Personal Advisers in National Government. Melbourne: Oxford University Press.

Whitaker, R. (2000). Politics versus Administration: Politicians and Bureaucrats. In M. Whittington, \& G. Williams (Eds.), Canadian Politics in the 21st Century (5th ed., pp. 55-78). Scarborough: Nelson, a Division of Thomas Learning.

Wicks, N. (2002). Defining the Boundaries within the Executive. Ministers, Special Advisers and Permanent Civil Servants. http://www.public-standards.gov.uk

Wildavsky, A. (1979). Speaking Truth to Power. The Art and Craft of Policy Analysis. Boston, MA: Little, Brown. https://doi.org/10.1007/978-1-349-04955-4

Wilson, S. H. (1976). Governance of Britain. London: Weidenfeld and Nicolson, and Michael Joseph.

Wilson, W. (1887). The Study of Administration. Political Science Quarterly, 2, 197-222. https://doi.org/10.2307/2139277

Yong, B., \& Hazell, R. (2014). Special Advisers. Who They Are, What They Do and Why They Matter. Oxford: Hart Publishing.

Young, H., \& Sloman, A. (1982). No, Minister. London: BBC Books. 